\title{
Effect of sugarcane fiber digestibility, conservation method and concentrate level on the ruminal ecosystem of beef cattle
}

\author{
Johnny Maciel de Souza', Dannylo Oliveira de Sousa', Bruno Souza de Mesquita², Lígia Garcia Mesquita' \\ and Luis Felipe Prada Silva ${ }^{1 *}$ (1)
}

\begin{abstract}
The aim of this study was to investigate the effects of sugarcane neutral detergent fiber digestibility (NDFD), conservation method, and concentrate level on the ruminal microbial population of steers. Eight ruminal-cannulated Nellore steers were distributed in two contemporary $4 \times 4$ Latin Square design with a $2 \times 2$ factorial arrangement of treatments. Experiment 1: diets were formulated with $60 \%$ of concentrate level, and two sugarcane genotypes (high or low NDFD) either freshly cut or as silage. Experiment 2: diets were formulated with two levels of concentrate (60 or $80 \%$ ), and two sugarcane genotypes (high or low NDFD) offered as freshly cut. Each experimental period lasted for 14 $\mathrm{d}$, with the last $4 \mathrm{~d}$ used for ruminal fluid collection. Three cellulolytic bacteria (Fibrobacter succinogenes, Ruminococcus albus, Ruminococcus flavefaciens), two amylolytic (Streptococcus bovis, Ruminobacter amylophilus), and a lactate fermenting microorganism (Megasphaera elsdenii) were quantified by qPCR. Experiment 1: diets with fresh sugarcane increased the population of S. bovis, and M. elsdenii. Sugarcane with high NDFD increased F. succinogenes population only when sugarcane was offered as freshly cut. Experiment 2: increasing concentrate in the diet decreased S. bovis population, and increased $R$. amylophilus. Sugarcane with high NDFD increased the population of cellulolytic bacteria only at the $60 \%$ concentrate diet. Providing sugarcane with high NDFD favored the growth of fibrolytic bacteria, and this effect were dependent on the conservation method and on diet concentrate level. In addition, sucrose appears to have great effect on the composition of ruminal microflora, especially S. bovis.
\end{abstract}

Keywords: Beef cattle, Ruminal fermentation, Ruminal microorganisms, qPCR, Sugarcane

\section{Introduction}

Feedlot diets have high inclusion of concentrate and low roughage, usually resulting in low ruminal $\mathrm{pH}$ that directly affects the digestibility of the fiber, and may also lead to metabolic disorders (Anderson et al. 2016). Fibrobacter succinogenes, Ruminococcus flavefaciens and Ruminococcus albus are considered the main bacteria responsible for roughage fiber degradation (Forsberg et al. 1997), and the proliferation of these microorganisms in the rumen is directly correlated with the quality and quantity of dietary fiber. Replacing fiber with

\footnotetext{
*Correspondence: Ifpsilva@usp.br

1 Department of Animal Science, School of Veterinary Medicine,

Universidade de São Paulo, Pirassununga, São Paulo 13635-900, Brazil

Full list of author information is available at the end of the article
}

non-fibrous carbohydrates (NFC), such as starch and sugars, influences the development of cellulolytic microorganisms, changing the dynamics of fermentation in the ruminal ecosystem (Tajima et al. 2001).

As the concentration of fermentable carbohydrates in the rumen increases, microbial growth is stimulated, increasing ruminal fermentation rate. On the other hand, increasing the digestibility of carbohydrates in the rumen results in $\mathrm{pH}$ to drop below 6.0 due to the greater production of short-chain fatty acids (SCFA). In this situation, there is a reduction in the activity of fibrolytic bacteria, affecting the digestibility of fiber, while there is increased activity of amylolytic bacteria, such as Streptococcus bovis and Ruminococcus amylophilus, and lactate users, as Megasphaera elsdenii (Tajima et al. 2001; Nagaraja and 
Titgemeyer 2007; Petri et al. 2012). The excess of ruminal fermentation of NFC, combined with low inclusion of roughage in the diet, can lead to acidosis, decreasing fiber digestibility, dry matter intake and, consequently, causing a reduction in weight gain of animals (Gonzalez et al. 2012).

Therefore, one alternative would be to use better quality roughages, reducing the diet concentrate content and favoring the proper development of cellulolytic microorganisms. Inclusion of high quality forage in the diet is positively related to growth of cellulolytic bacteria populations in the rumen (Fernando et al. 2010; Koike and Kobayashi 2001). Among the roughages, sugarcane is widely used as forage in diets for ruminants, either as freshly cut or ensiled (Freitas et al. 2006). However, beside low protein content, poor fiber digestibility is the main limitation of animal performance in sugarcanebased diets (Pereira et al. 2001). Moreover, sugarcane has high sucrose content, and despite the importance of fiber digestibility for animal performance, the sugarcane breeding programs are focused on total production of sucrose, with little attempt to evaluate quality parameters for animal nutrition. Forage breeding demonstrates that small increases in dry matter (DM) digestibility result in significant improvement in animal performance (Casler 2001).

In this context, it is important to understand how neutral detergent fiber digestibility (NDFD) of sugarcane genotypes, the level of concentrate, and the method of conservation affects the population dynamics of ruminal microorganisms. The ensiling process changes the chemical composition of sugarcane, increasing fiber and reducing the sucrose content (Kung and Stanley 1982; Daniel et al. 2013), altering the ruminal fermentation (Hungate 1966; Vallimont et al. 2004; Singh et al. 2014). These factors directly affect the mechanisms involved in fiber degradation by ruminal microorganism. Therefore, the objectives of this study were to evaluate the effect of NDFD and conservation method of sugarcane, and the concentrate level in the diet on the population of ruminal bacteria of cannulated beef cattle.

\section{Materials and methods}

All experimental procedures were in agreement with the Guide for Care and Use of Agricultural Animals in Agricultural Research and Teaching (FASS 1999), with all animal procedures approved by the University of São Paulo Animal Bioethics Committee (Protocol number 7632051113).

For this experiment, samples of rumen contents coming from two previous experiments were used (Mesquita 2013; Sousa et al. 2014), which presented the results of performance and ruminal kinetics. The experiments were conducted at the College of Veterinary Medicine and Animal Science, University of São Paulo Beef Cattle Research Laboratory (Pirassununga, SP, Brazil). In both developed experiments, rumen contents samples were collected from cannulated animals for quantification on the ruminal microorganisms of interest.

\section{Animals and diets}

In the first experiment (Sousa et al. 2014), eight ruminalcannulated Nellore steers were distributed in two contemporary $4 \times 4$ Latin Square design. Experimental diets were formulated with $40 \%$ sugarcane, either freshly cut or as silage, and $60 \%$ concentrate on a DM basis. As roughage, two genotypes with high or low digestibility of NDF (NDFD) were used, making up 4 experimental diets in a $2 \times 2$ factorial arrangement of treatments ( 2 modes of conservation and 2 NDFD).

In the second experiment (Mesquita 2013), eight ruminal-cannulated Nellore steers were distributed in two contemporary $4 \times 4$ Latin square design. Experimental diets were formulated with 40 or $60 \%$ of fresh sugarcane, and two levels of concentrate on a DM basis. As roughage, two genotypes with high or low NDFD were used, making up four experimental diets in a $2 \times 2$ factorial arrangement of treatments (two levels of concentrate and two NDFD).

In both experiments, the sugarcane genotypes used were IAC86-2480 (high NDFD) and SP91-1049 (low NDFD). The genotype IAC $86-2480$ was confirmed as having $20.5 \%$ greater NDFD than the genotype SP911049 (38.5 vs. $32.0 \pm 1.1 \%$ ). The diets were formulated according to NRC (1996), aiming a weight gain of $1.2 \mathrm{~kg} /$ day. The concentrate was composed of ground corn (46.7\% DM basis), soybean meal (10\% DM basis), urea (1.24\% DM basis), limestone (0.50\% DM basis), salt (0.25\% DM basis) and a commercial mineral supplement (1.3\% DM, Minerthal MD $\left.{ }^{\circledR}\right)$. The diets were fed ad libitum twice daily, and the control of feed was done individually, by daily weighing of food provided and remains, allowing between 5 and $10 \%$ of orts. The steers were kept in tie stalls with concrete floors, individual feeders, and water bunks. No bedding was used. Stalls and bunks were cleaned daily. A detailed description of the diets can be found at Mesquita (2013) and Sousa et al. (2014).

Each experimental period lasted 14 days, with 10 days for diet adaptation and the last 4 days used for determination of consumption (dry matter intake, DMI; and indigestible neutral detergent fiber, iNDF), ruminal evacuation and collection of ruminal fluid. Steers were weighed weekly for 2 consecutive days, without water or feed restriction. 


\section{Collection and processing of rumen contents}

For both experiments, the ruminal content was evacuated manually through the rumen cannula in fasted animals $(0 \mathrm{~h}$ after feeding) and $4 \mathrm{~h}$ after eating. The total mass of ruminal content and volume were determined. During the evacuation, an aliquot of $10 \%$ was separated for sub-sampling facility. $600 \mathrm{~mL}$ of a representative sample of the liquid and solid phase (proportional) was used to determination of the bacterial population, and the unused rumen contents were returned to each steer via the fistula. These samples were stored properly in a freezer at $-20{ }^{\circ} \mathrm{C}$.

For each sample, $25 \mathrm{~mL}$ of fluid and $25 \mathrm{~g}$ of solids were used for processing, as described by Stevenson and Weimer (2007), and the resulting bacteria pellet was dissolved in $700 \mu \mathrm{L}$ of buffer $(100 \mathrm{mM}$ Tris $/ \mathrm{HCl}, 10 \mathrm{mM}$ EDTA, and $0.15 \mathrm{M} \mathrm{NaCl}, \mathrm{pH} 8.0)$ and stored at $-80{ }^{\circ} \mathrm{C}$ until DNA extraction.

\section{qPCR of ruminal bacteria}

Three cellulolytic bacteria (F. succinogenes, $R$. albus and $R$. flavefaciens), two amylolytic (S. bovis and Ruminobacter amylophilus), and a lactate fermenting microorganism (M. elsdenii) were quantified by the technique of qPCR to determine the effect of diet on the population of ruminal microorganisms.

DNA extraction was performed for each sample of rumen content, with QIAamp DNA Stool Mini Kit (Qiagen, Valencia, CA) and used according to the manufacturer's instructions. For extraction, $200 \mu \mathrm{L}$ of ruminal content per sample were used. Based on the study of Henderson et al. (2013), although the total yield of DNA from this particular kit was lower than extraction with phenol chloroform-based methods, it produces DNA with good quality for PCR amplification from cow rumen contents. The real-time qPCR reactions were performed in 96-well plates on a 7500 Real Time PCR System (Applied Biosystems ${ }^{\circledR}$, Life Technologies, Foster City, CA) for each ruminal sample individually, containing 10 $\mu \mathrm{L}$ of $2 \times$ SYBR Green Master Mix (Applied Biosystems ${ }^{\circledR}$, Life Technologies, Foster City, CA), $1.2 \mu \mathrm{L}$ of primer Forward and $1.2 \mu \mathrm{L}$ of primer Reverse for respective bacteria (Table 1), $6.6 \mu \mathrm{L}$ of MilliQ water, and $1 \mu \mathrm{L}$ of DNA template in a final volume of $20 \mu \mathrm{L}$ per reaction.

A universal primer was used for quantification of total bacteria (Table 1) for each ruminal sample individually, to standardize the amount of DNA added to the reactions, following the same qPCR conditions describe above. The qPCR reactions of all bacteria were run in duplicate, and a negative control was included in each assay to assess the specificity of qPCR reaction.

The qPCR amplification protocol was as follows: an initial denaturation step at $95^{\circ} \mathrm{C}$ for $10 \mathrm{~min}$, then 44 cycles of heating and cooling at $95{ }^{\circ} \mathrm{C}$ for $15 \mathrm{~s}$, followed by annealing step at $60{ }^{\circ} \mathrm{C}$ for $30 \mathrm{~s}$, and extension at $72{ }^{\circ} \mathrm{C}$ for $30 \mathrm{~s}$. Melting curves were analyzed at the end of the reactions to verify the specificity of each amplification.

\section{Statistical analysis}

Data from the two experiments were analyzed separately. The data were analyzed in a contemporary Latin square design, using the MIXED procedure of SAS version 9.3, which previously verified the normality of residuals by the Shapiro-Wilk's test and the homogeneity of variances compared by Levene's test. The data of relative quantification of ruminal bacteria by qPCR were analyzed by analysis of covariance, according to the model of relative expression proposed by Yuan et al. (2006). For the first experiment, the model included the fixed effects of sugarcane neutral detergent fiber digestibility (NDFD),

Table 1 Real-time PCR primers used in the relative quantification of ruminal microorganisms

\begin{tabular}{|c|c|c|c|}
\hline Species & Sequence $\left(5^{\prime}-3^{\prime}\right)$ & Amplicon size (bp) & Reference \\
\hline F. succinogenes & $\begin{array}{l}\text { F: GGTATGGGATGAGCTTGC } \\
\text { R: GCCTGCCCCTGAACTATC }\end{array}$ & 445 & Tajima et al. (2001) \\
\hline R. albus & $\begin{array}{l}\text { F: CCCTAAAAGCAGTCTTAGTTCG } \\
\text { R: CCTCCTTGCGGTTAGAACA }\end{array}$ & 175 & Wang et al. (1997) \\
\hline R. flavefaciens & $\begin{array}{l}\text { F:TCTGGAAACGGATGGTA } \\
\text { R:CCTTTAAGACAGGAGTTTACA }\end{array}$ & 295 & Koike and Kobaiashi (2001) \\
\hline S. bovis & $\begin{array}{l}\text { F: CTAATACCGCATAACAGCAT } \\
\text { R: AGAAACTTCCTATCTCTAGG }\end{array}$ & 127 & Stevenson and Weimer (2007) \\
\hline R. amylophilus & $\begin{array}{l}\text { F: CAACCAGTCGCATTCAGA } \\
\text { R: CACTACTCATGGCAACAT }\end{array}$ & 642 & Tajima et al. (2001) \\
\hline M. elsdenii & $\begin{array}{l}\text { F: GACCGAAACTGCGATGCTAGA } \\
\text { R: CGCCTCAGCGTCAGTTGTC }\end{array}$ & 129 & Ouwerkerk et al. (2002) \\
\hline Eubacteria & $\begin{array}{l}\text { F: CCTACGGGAGGCAGCAG } \\
\text { R: ATTACCGCGGCTGCTGG }\end{array}$ & 193 & Muyzer et al. (1993) \\
\hline
\end{tabular}


conservation method (CONS), and their interaction. The square effect, animal inside square and period were included as random factors in the model. For the second experiment, the model included the fixed effects of level of concentrate (DIET), sugarcane NDF digestibility (NDFD), and their interaction. The square effect, animal inside square and period were included as random factors in the model. In both models, the repeated measures factor was included, relating to different times of rumen content collection. The degrees of freedom and tests were adjusted using the Kenward-Roger option. Treatment means were compared with the least significant difference and significance declared at the 0.05 probability level. When significance of the interaction between the main effects was $\leq 0.10$, the interaction was decomposed and the treatments effects were analyzed by using the SLICE option of PROC MIXED. Data is presented as percentage of total microbial population.

\section{Results}

Study 1

In the first study, the effect of fiber digestibility on $F$. succinogenes population was dependent on the forage conservation method, as there was a significant NDFD $\times$ CONS interaction $(P=0.01$; Table 2$)$. Feeding diets containing the high-NDFD sugarcane genotype increased $(P<0.01)$ F. succinogenes population, but only when fed as fresh sugarcane and not when fed as silage.

The sugarcane genotype, as well as the conservation method, did not influence the population of $R$. albus ( $P=0.12$ and $P=0.17$, respectively), and $R$. flavefaciens ( $P=0.37$ and $P=0.27$, respectively). There was no significant interaction between the factors described for both ruminal microorganisms $(P=0.91$ and $P=0.59$, respectively).
The sugarcane genotype did not affect the population of $S$. bovis $(P=0.53)$ and $M$. elsdenii $(P=0.61)$. However, the supply of sugarcane as freshly cut increased the population of $S$. bovis $(0.019$ vs $0.003 \%, P<0.01)$ and $M$. elsdenii ( 0.073 vs $0.013 \%, P=0.06)$ when compared to feeding sugarcane as silage (Table 2).

Ruminal content collection time also affected the relative population of ruminal bacteria. There was a reduction in $F$. succinogenes relative population after feeding $(P=0.03)$, whereas the relative population of $R$. amylophilus $(P<0.01)$ and $M$. elsdenii $(P<0.01)$ was greater $4 \mathrm{~h}$ after feeding (Table 3).

\section{Study 2}

In the second study, the effect of fiber digestibility on $F$. succinogenes, $R$. albus and $R$. flavefaciens populations was dependent on the concentrate level of the diet, as there was a significant NDFD $\times$ Diet interaction $(P=0.06$, $P<0.01$, and $P=0.09$ respectively; Table 4 ). Feeding diets containing the high-NDFD sugarcane genotype increased the populations of $F$. succinogenes $(P<0.01)$ and of $R$. albus $(P<0.01)$, but only in the diet with $60 \%$ concentrate, and not in the $80 \%$ concentrate diet. However, the opposite effect was observed for the $R$. flavefaciens population, where feeding the high-NDFD sugarcane genotype increased $(P<0.01) R$. flavefaciens population only at the $80 \%$ concentrate diet.

Furthermore, the increase of concentrate in the diet, from 60 to $80 \%$, resulted in a significant reduction in the population of $S$. bovis $(0.022$ vs $0.004 \%, P<0.01)$. On the other hand, there was an increase in population of $R$. amylophilus $(0.012$ vs $0.021 \%, P=0.07)$ in response to the increase of concentrate in the diet. There were no effects of the diet, NDFD or the interaction between these factors on the population of M. elsdenii $(P>0.10)$.

Table 2 Relative population of ruminal microorganisms in function of digestibility of neutral detergent fiber (high or low NDFD) and conservation method (fresh or silage) of sugarcane, considering the means of two collection times

\begin{tabular}{|c|c|c|c|c|c|c|c|c|}
\hline \multirow[t]{2}{*}{ Species } & \multicolumn{2}{|l|}{ Fresh } & \multicolumn{2}{|l|}{ Silage } & \multirow[t]{2}{*}{ SEM } & \multicolumn{3}{|l|}{$P$ value } \\
\hline & Low NDFD ${ }^{1}$ & High NDFD ${ }^{2}$ & Low NDFD ${ }^{1}$ & High NDFD ${ }^{2}$ & & NDFD & Cons & NDFD*Cons \\
\hline F. succinogenes & $0.014^{\mathrm{a}}$ & $0.036^{a}$ & $0.023^{a b}$ & $0.009^{b}$ & 0.050 & 0.98 & 0.22 & 0.01 \\
\hline R. albus & 0.002 & 0.004 & 0.001 & 0.002 & 0.004 & 0.12 & 0.17 & 0.91 \\
\hline R. flavefaciens & 0.013 & 0.008 & 0.006 & 0.005 & 0.006 & 0.37 & 0.27 & 0.59 \\
\hline S. bovis & 0.025 & 0.015 & 0.003 & 0.003 & 0.009 & 0.53 & $<0.01$ & 0.47 \\
\hline R. amylophilus & 0.013 & 0.009 & 0.013 & 0.007 & 0.004 & 0.13 & 0.82 & 0.77 \\
\hline M. elsdenii & 0.102 & 0.053 & 0.012 & 0.013 & 0.075 & 0.61 & 0.06 & 0.51 \\
\hline
\end{tabular}

The relative population size is presented as percentage of total microbial population NDFD effect of NDF digestibility, Cons effect of conservation method

a,b Means within a row with different superscript letters differ, $P<0.05$

1 SP91-1049 sugarcane genotype

2 IAC86-2480 sugarcane genotype 
Table 3 Relative population of ruminal microorganisms, in function of time of collection of ruminal content, of both studies

\begin{tabular}{|c|c|c|c|c|c|c|c|c|}
\hline \multirow[t]{2}{*}{ Species } & \multicolumn{2}{|c|}{ Study 1} & \multirow[t]{2}{*}{ SEM } & \multirow[t]{2}{*}{$P$ value } & \multicolumn{2}{|c|}{ Study 2} & \multirow[t]{2}{*}{ SEM } & \multirow[t]{2}{*}{$P$ value } \\
\hline & $\mathrm{Oh}$ & $4 \mathrm{~h}$ & & & $\mathrm{Oh}$ & $4 \mathrm{~h}$ & & \\
\hline F. succinogenes & 0.024 & 0.013 & 0.005 & 0.03 & 0.010 & 0.012 & 0.004 & 0.57 \\
\hline R. albus & 0.002 & 0.002 & 0.001 & 0.54 & 0.004 & 0.003 & 0.002 & 0.77 \\
\hline R. flavefaciens & 0.007 & 0.009 & 0.002 & 0.31 & 0.012 & 0.016 & 0.004 & 0.31 \\
\hline S. bovis & 0.008 & 0.007 & 0.002 & 0.55 & 0.014 & 0.006 & 0.003 & $<0.01$ \\
\hline R. amylophilus & 0.005 & 0.021 & 0.003 & $<0.01$ & 0.008 & 0.032 & 0.005 & $<0.01$ \\
\hline M. elsdenii & 0.017 & 0.054 & 0.009 & $<0.01$ & 0.098 & 0.251 & 0.046 & $<0.01$ \\
\hline
\end{tabular}

The relative population size is presented as percentage of total microbial population

Table 4 Relative population of ruminal microorganisms in function of digestibility of neutral detergent fiber (high or low NDFD) of fresh sugarcane and level of concentrate in diet (60 or $80 \%)$, considering the means of two collection times

\begin{tabular}{|c|c|c|c|c|c|c|c|c|}
\hline \multirow[t]{2}{*}{ Species } & \multicolumn{2}{|c|}{$60 \%$ concentrate } & \multicolumn{2}{|c|}{$80 \%$ concentrate } & \multirow[t]{2}{*}{ SEM } & \multicolumn{3}{|c|}{$P$ value } \\
\hline & Low NDFD ${ }^{1}$ & High NDFD ${ }^{2}$ & Low NDFD ${ }^{2}$ & High NDFD ${ }^{2}$ & & NDFD & Diet & NDFD*Diet \\
\hline F. succinogenes & $0.012^{b}$ & $0.023^{\mathrm{a}}$ & $0.010^{b}$ & $0.006^{b}$ & 0.005 & 0.74 & 0.02 & 0.06 \\
\hline R. albus & $0.002^{b}$ & $0.012^{\mathrm{a}}$ & $0.004^{a b}$ & $0.002^{b}$ & 0.003 & 0.21 & 0.20 & $<0.01$ \\
\hline R. flavefaciens & $0.012^{a b}$ & $0.008^{b}$ & $0.013^{a b}$ & $0.031^{a}$ & 0.007 & 0.49 & 0.07 & 0.09 \\
\hline S. bovis & 0.024 & 0.019 & 0.004 & 0.005 & 0.008 & 0.94 & $<0.01$ & 0.57 \\
\hline R. amylophilus & 0.015 & 0.009 & 0.021 & 0.021 & 0.006 & 0.47 & 0.07 & 0.37 \\
\hline M. elsdenii & 0.145 & 0.070 & 0.237 & 0.254 & 0.106 & 0.38 & 0.25 & 0.29 \\
\hline
\end{tabular}

The relative population size is presented as percentage of total microbial population NDFD effect of NDF digestibility (NDFD), Diet effect of level of concentrate in diet

a,b Means within a row with different superscript letters differ, $P<0.05$

1 SP91-1049 sugarcane genotype

2 IAC86-2480 sugarcane genotype

Regarding the time of rumen content collection, there was a reduction in the population of $S$. bovis $4 \mathrm{~h}$ after feeding $(P<0.01)$, whereas the population of $R$. amylophilus $(P<0.01)$ and of $M$. elsdenii $(P<0.01)$ was greater $4 \mathrm{~h}$ after feeding (Table 3 ).

\section{Discussion}

Forage quality is an important factor regulating intake and efficiency of diet utilization, as well as in reducing the amount of concentrate in the diet of ruminants (Tafaj et al. 2005). Sugarcane has a particular physiological maturation process, as with the advance of maturity there is a decrease in fiber digestibility and in CP content. However, because of sucrose accumulation, there is an increase in NFC content leading to increase the total DM digestibility as maturity progress (Kung and Stanley 1982; Carvalho et al. 2010). However, the effect of sugar, like sucrose, on ruminal microorganisms has not been extensively studied (Sun et al. 2015). Therefore, low fiber digestibility is usually the main limiting factor for high performance beef cattle fed with sugarcane based diets, as NDF digestibility in sugarcane can be about half of that of corn silage (Corrêa et al. 2003).

The proportion of high quality forage in the diet exerts a positive influence on growth of cellulolytic bacteria in the rumen (Fernando et al. 2010), increasing intake and, consequently, animal performance. Thus, we hypothesized that modulation of animal performance by diet could be explained by modulation of the population of ruminal microorganisms. In the present study, the use of a sugarcane genotype with high-NDF digestibility favored growth of fibrolytic bacteria in the rumen, likely by substrate availability and maintenance of optimum rumen $\mathrm{pH}$. To our knowledge, no other study evaluated the change in ruminal bacteria population to differing fiber digestibility of the roughage.

It is important to consider that in the present study, both liquid and solid fractions were analyzed together, which could potently mask important population changes happening in each of the fractions separately. Also, the method of DNA extraction can also influence the results, although the variation between DNA extraction methods 
is usually smaller than the variation caused by changes in diet (Henderson et al. 2013).

In the present study, the two different sugarcane genotypes had different chemical composition. The lignin and indigestible FDN contents were lower for the highNDFD genotype, with greater DM and NDF digestibility (Sousa et al. 2014; Mesquita 2013). In the first study, the effect of greater NDF digestibility of sugarcane on F. succinogenes population was dependent on the method of conservation. F. succinogenes was increased with highNDF digestibility, when sugarcane was offered as freshly cut. The $R$. albus population followed a similar pattern, although not significant $(P=0.12)$. The silage process alters the nutritional quality of roughages, where part of the NFC is consumed, and causing increase in the NDF and lignin concentration (Kung and Stanley 1982). Mode of conservation changed the chemical composition of sugarcane, with greater lignin and iNDF in the ensiled sugarcane, while DM and NDF digestibility were greater for the freshly-cut sugarcane. Therefore, when sugarcane is offered as freshly cut there is more soluble sugar arriving in the rumen environment. Consequently, mode of conservation influenced rumen $\mathrm{pH}$, with greater rumen $\mathrm{pH}$ when sugarcane was offered as silage than as freshly cut (6.69 vs. $6.37 \pm 0.08 ; P<0.01)$. There was no effect of sugarcane genotype on rumen $\mathrm{pH}$ levels (Sousa et al. 2014). According to Tafaj et al. (2005), a moderate quantity of NFC in the diet can stimulate fiber digestibility because of better supply of fermentable organic matter, nitrogen, and energy for the ruminal bacteria.

Among the cellulolytic bacteria present in the rumen, F. succinogenes, R. flavefaciens, and R. albus are considered the main species responsible for fiber degradation (Varel and Dehority 1989). Therefore, proliferation of cellulolytic bacteria in the rumen would be correlated with the amount of digestible fiber in the diet, and the substitution of fiber for soluble carbohydrates would influence its growth and alter the dynamic of the rumen ecosystem (Tajima et al. 2001). In the second experiment, the effect of high-NDF digestibility on the population of these three species of fibrolytic bacteria was dependent on the level of concentrate in the diet; where the population of $F$. succinogenes and $R$. albus responded to high-NDF digestibility only at the lower level of concentrate inclusion. However, R. flavefaciens population responded to highNDFD only in the diet with $80 \%$ concentrate. In study 2 , rumen $\mathrm{pH}$ was influenced only by concentrate level, where the $60 \%$ concentrate diet had greater mean rumen $\mathrm{pH}$ than the $80 \%$ concentrate $\operatorname{diet}(6.38$ vs. $6.12 \pm 0.11$, $P<0.05$, Mesquita 2013). Although the three studied species $F$. succinogenes, $R$. flavefaciens, and $R$. albus are considered important rumen cellulolytic bacteria, their mechanism of action, ability to adhere to particles and enzymatic profiles are different (Mosoni et al. 1997). When cultured with excess cellulose, the number of cells for these three species was similar (Shi et al. 1997). However, when cultured with limited amount of cellulose, $R$. flavefaciens predominated over the other two, demonstrating the superior adhesion capacity for this microorganism (Shi et al. 1997). In the context of study 2, diets with the high-NDFD sugarcane genotype increased the total intake, NDF rumen passage rate and body growth of the animals, but only in the diet with $80 \%$ concentrate (Mesquita 2013). Also, the diet with $80 \%$ concentrate reduced rumen ammonia levels $(11.66$ vs. $7.18 \mathrm{mg} / \mathrm{dL}$ for the 60 and $80 \%$ concentrate diets, respectively-Mesquita 2013).

With the increment of fermentable carbohydrates in the rumen, there is an overall stimulus for microbial fermentation. On the other hand, rapidly fermentable carbohydrates and the accumulation of SCFA in the rumen forces a decline in ruminal $\mathrm{pH}$, usually for values bellow 6.0. In these situations, there is a reduction in the activity of fibrolytic bacteria, hindering fiber digestibility (Weimer 1996; Owens et al. 1998; Russell and Rychlik 2001) while simultaneously stimulating amylolitic and lactate utilizing-bacteria (Tajima et al. 2001; Nagaraja and Titgemeyer 2007). Besides direct inhibition of cellulolytic bacteria with low ruminal $\mathrm{pH}$, there is also a decline in attachment of bacteria to the substrate, caused by the lack of positive effectors, such as the ion bicarbonate, and by the excess of attachment inhibitors, such as soluble starch (Owens and Goetsch 1993).

Petri et al. (2012) observed that great inclusion of concentrate in the diet, in substitution for the roughage, reduces the populations of the fibrolytic bacteria $F$. succinogenes, $R$. flavefaciens, and $R$. albus. The substitution of roughage for concentrate, rich in rapidly fermentable carbohydrates, promoted a decline in particle size of the diet, with less physically effective NDF, reducing salivation and rumen motility and, consequently, rumen buffering. Several other studies demonstrate the reduction in cellulolytic bacteria due to the increase in concentrate in the diet (Tajima et al. 2001; Singh et al. 2014; GranjaSalcedo et al. 2016).

Different from the fibrolytic bacteria, the amilolytic bacteria (represented in this study by $R$. amylophilus and $S$. bovis) have preference for NFC and are more tolerant to low $\mathrm{pH}$. In the present study, there was an increase in the population of $R$. amylophilus with greater concentrate inclusion in the diet, reflecting the increase in starch and total NFC in the diet (Schwartzkopf-Genswein et al. 2003; Petri et al. 2012). However, the S. bovis population was reduced with greater concentrate in the diet, and was increased with freshly cut sugarcane compared to sugarcane conserved as silage. It is important to highlight that 
the roughage used in this study was sugarcane, with high level of soluble sugars (mainly sucrose). Also, sugarcane as silage has lower sugar content than freshly cut sugarcane. Therefore, in the present study, the treatments that provided more soluble sugar and less starch to the rumen (lower concentrate inclusion and freshly cut sugarcane) favored growth of $S$. bovis. Hence it can be suggested that $S$. bovis prefer NFC sources other than starch, such as sucrose.

Supporting this hypothesis, Golder et al. (2014) reported that $S$. bovis became more prevalent in heifers fed with fructose than with starch. Moreover, the relative abundance of the Streptococcaceae and Veillonellaceae families was increased when heifers received fructose. Other studies found similar results, where the population of S. bovis was not increased with the increment of concentrate in the diet of Nellore steers, using corn silage as the roughage source (Granja-Salcedo et al. 2016) or freshly-cut sugarcane (Ribeiro Junior et al. 2016). Sun et al. (2015) report an increase of S. bovis population by replacing cornstarch in a high-concentrate diet (forage to concentrate ratio $=40: 60$ ) with $3 \%$ sucrose after $24 \mathrm{~h}$ in vitro incubation.

The ruminal bacteria $S$. bovis is a facultative anaerobe and tolerant to low $\mathrm{pH}$, and is known to be prevalent during lactic acidosis, proliferating in the rumen of cattle fed high levels of concentrate (Owens et al. 1998; Russell and Hino 1985; Russell and Rychlik 2001). However, the fast growth of S. bovis was not observed in animals adapted to starch rich diets, but in animals with lactic acidosis (Nagaraja and Titgemeyer 2007). Fernando et al. (2010) reported that the population of S. bovis increased at the beginning of the adaptation regimen to high grain diet, whereas at the end of the step-up adaptation, the S. bovis population decreased, and did not show a significant change in population size compared to control, where animals received only hay during the adaptation phase.

Therefore, whether the animals are adapted or not to a high-grain diet seems to influence the effect of addition of grains in the S. bovis population in the rumen. The abrupt change in the diet in non-adapted animals favors the rapid growth of S. bovis, lactate and SCFA accumulation, decline in rumen $\mathrm{pH}$, and metabolic disorders (Russell and Hino 1985; Hernandez et al. 2014). In contrast, when animals are adapted to high-grain diets, the $S$. bovis population can be controlled favoring the growth of lactate utilizers, such as M. elsdenii and Selenomonas ruminantium, and the maintenance of rumen $\mathrm{pH}$ (Fernando et al. 2010). Hence, the importance of removal of fermentation acids, specially lactate, so as not to cause the decline in rumen $\mathrm{pH}$.

Some microorganism present in the rumen and tolerant to low $\mathrm{pH}$ can utilize lactate, therefore avoiding lactate accumulation in the rumen environment. The lactate utilizing bacteria measured in the present study was M. elsdenii, which population increased when sugarcane was offered as freshly cut as opposed to sugarcane silage. This microorganism is able to grow on sucrose or glucose, although from these substrates the end product is butyrate, not propionate which comes from lactate (Hino et al. 1994). In the study 2 , there was greater proportion of butyric acid in the rumen of animals receiving diets with $60 \%$ concentrate in comparison to $80 \%$ of concentrate $(15.67$ vs. $13.28 \%$ of total SCFA, $P=0.01-$ Mesquita 2013), and this can be explained by the action of $M$. elsdenii. This increase in molar proportion of butyrate in response to the partial substitution of starch with sugar was consistent to previous studies (Vallimont et al. 2004; Sun et al. 2015).

Khafipour et al. (2009) reported that S. bovis was the prevalent species during severe acidosis and that $M$. elsdenii was the dominant species during mild acidosis caused by excess of grain in the diet. Also, strains of M. elsdenii has been used to reduce lactate accumulation and increases rumen $\mathrm{pH}$, consequently preventing ruminal acidosis (Long et al. 2014). In the present study, the diet with fresh sugarcane provided more sucrose to the rumen, favoring rumen fermentation and more acid accumulation, including lactate. The transient increase in lactate would favor growth of M. elsdenii.

It is clear that NFC supply to the rumen alter the fermentation profile and therefore the ruminal microorganism populations. This fact becomes evident when the different sampling times are considered. When rumen samples were collected shortly after feeding, when there is a great supply of NFC to the rumen, there was a reduction in the population of $F$. succinogenes and an increase in the populations of $R$. amylophilus and M. elsdenii. Similar results have been reported in ovine by Mosoni et al. (2007), with a reduction in the populations of fibrolytic bacteria (F. succinogenes, $R$. albus, and $R$. flavefaciens) when the rumen was sampled $3 \mathrm{~h}$ after feeding. The population of another lactate utilizing bacteria, $S$. ruminantium, was also increased $2 \mathrm{~h}$ after feeding (Singh et al. 2014). The rumen is a complex and dynamic environment where the microorganisms must constantly adapt to changes in diet composition, amount and frequency of feeding.

Therefore, the supply of sugarcane with greater NDFD favored the growth of fibrolytic bacteria, but this effect was dependent on the conservation method and the concentrate level. The genotype with higher NDFD favored the growth of $F$. succinogenes only when sugarcane was offered as freshly cut. Furthermore, on a diet with less addition of concentrate, the population of fibrolytic bacteria $F$. succinogenes and $R$. albus increased 
in response to increasing NDFD. When sugarcane was offered as freshly cut, the population of S. bovis and $M$. elsdenii were increased in response to greater supply of readily fermentable sugars. In addition, the increase of dietary concentrate increased the population of $R$. amylophilus and reduced $F$. succinogenes, $R$. albus and S. bovis, highlighting the hypothesis that $S$. bovis has a higher affinity for sugar (Additional file 1) than the for starch itself.

\section{Additional file}

Additional file 1. Results of qPCR amplification of $F$. succinogenes, $R$. flavefaciens, R. albus, S. bovis, R. amylophilus, and M. elsdenii.

\section{Abbreviations}

NDFD: neutral detergent fiber digestibility; NDF: neutral detergent fiber; qPCR: quantitative polymerase chain reaction; NFC: non-fibrous carbohydrates; SCFA: short-chain fatty acids; DM: dry matter; DMI: dry matter intake; iNDF: indigestible neutral detergent fiber; CONS: conservation method; DIET: level of concentrate.

\section{Authors' contributions}

LFPS and JMS designed research; JMS performed research; DOS and BSM assisted with the experiments; LGM assisted partly with laboratory analysis. LFPS and JMS analyzed data and wrote the paper. All authors read and approved the final manuscript.

\section{Author details}

1 Department of Animal Science, School of Veterinary Medicine, Universidade de São Paulo, Pirassununga, São Paulo 13635-900, Brazil. ${ }^{2}$ Ouro Fino Saúde Animal, Cravinhos, São Paulo 14140-000, Brazil.

\section{Competing interests}

The authors declare that they have no competing interests.

\section{Availability of data and materials}

The dataset supporting the conclusions of this article is included within the article. Additional supporting file-Dataset_Study 1\&2_AMB_Johnny.xls.

\section{Ethics approval and consent to participate}

All applicable international, national, and/or institutional guidelines for the care and use of animals were followed (University of São Paulo Animal Bioethics Committee, Protocol Number 7632051113).

\section{Funding}

This study was funded by São Paulo Research Foundation-FAPESP (Grants: 2013/22811-0 and 2009/00976-2).

Received: 20 December 2016 Accepted: 24 February 2017

Published online: 06 March 2017

\section{References}

Anderson CL, Schneider CJ, Erickson GE, MacDonald JC, Fernando SC (2016) Rumen bacterial communities can be acclimated faster to high concentrate diets than currently implemented feedlot programs. J Appl Microbiol 120:588-599. doi:10.1111/jam.13039

Carvalho MV, Rodrigues PHM, Lima MLP, Anjos IA, Landell MGA, Santos MV, e Silva LFP (2010) Chemical composition and digestibility of sugarcane harvested at two periods of the year. Braz J Vet Res Anim Sci 47:298-306. doi:10.11606/issn.1678-4456.bjvras.2010.26829

Casler MD (2001) Breeding forage crops for increased nutritional value. Adv Agron 71:51-107. doi:10.1016/S0065-2113(01)71012-7
Corrêa CES, Pereira MN, Oliveira SG, Ramos MH (2003) Performance of holstein cows fed sugarcane or corn silages of different grain textures. Sci Agricola 60:621-629. doi:10.1590/S0103-90162003000400003

Daniel JLP, Amaral RC, Goulart RS, Zopollatto M, Santos VP, Toledo SG, CabezasGarcia EH, Lima JR, Santos MC, Nussio LG (2013) Short-term effects of silage volatile compounds on feed intake and digestion in beef cattle. $J$ Anim Sci 91:2321-2331. doi:10.2527/jas2012-5657

Fernando SC, Purvis HT, Najar FZ, Sukharnikov LO, Krehbiel CR, Nagaraja TG, Roe BA, Desilva U (2010) Rumen microbial population dynamics during adaptation to a high-grain diet. Appl Environ Microbiol 76:7482-7490. doi:10.1128/AEM.00388-10

Forsberg CW, Cheng KJ, White BA (1997) Polysaccharide degradation in the rumen and large intestine. In: Mackie RI, White BA (eds) Gastrointestinal microbiology. Chapman and Hall, New York, pp 319-379

Freitas AWP, Pereiram JC, Rocha FC, Detmann E, Barbosa MHP, Ribeiro MD, Costa MG (2006) Evaluation of the nutritional divergence of sugarcane (Saccharum spp.) genotypes. Braz J Anim Sci 35:229-236. doi:10.1590/ S1516-35982006000100029

Golder HM, Denman SE, McSweeney C, Celi P, Lean IJ (2014) Ruminal bacterial community shifts in grain-, sugar-, and histidine-challenged dairy heifers. J Dairy Sci 97:5131-5150. doi:10.3168/jds.2014-8003

Gonzalez LA, Manteca X, Calsamiglia S, Schwartzkopf-Genswein KS, Ferret A (2012) Ruminal acidosis in feedlot cattle: interplay between feed ingredients, rumen function and feeding behavior (a review). Anim Feed Sci Tech 172:66-79. doi:10.1016/j.anifeedsci.2011.12.009

Granja-Salcedo YT, Ribeiro Junior CS, de Jesus RB, Gomez-Insuasti AS, Rivera AR, Messana JD, Canesin RC, Berchielli TT (2016) Effect of different levels of concentrate on ruminal microorganisms and rumen fermentation in Nellore steers. Arch Anim Nutr 70:17-32. doi:10.1080/17450 39X.2015.1117562

Henderson G, Cox F, Kittelmann S, Miri VH, Zethof M, Noel SJ, Waghorn GC, Janssen PH (2013) Effect of DNA extraction methods and sampling techniques on the apparent structure of cow and sheep rumen microbial communities. PLoS ONE. doi:10.1371/journal.pone.0074787

Hernandez J, Benedito JL, Abuelo A, Castillo C (2014) Ruminal acidosis in feedlot: from aetiology to prevention. Sci World J 2014:702572. doi:10.1155/2014/702572

Hino T, Shimada K, Maruyama T (1994) Substrate preference in a strain of Megasphaera elsdenii, a ruminal bacterium, and its implications in propionate production and growth competition. Appl Environ Microb 60:1827-1831

Hungate RE (1966) The rumen and its microbes. Academic Press, New York

Khafipour E, Krause DO, Plaizier JC (2009) A grain-based subacute ruminal acidosis challenge causes translocation of lipopolysaccharide and triggers inflammation. J Dairy Sci 92:1060-1070. doi:10.3168/jds.2008-1389

Koike S, Kobayashi Y (2001) Development and use of competitive PCR assays for the rumen cellulolytic bacteria: Fibrobacter succinogenes, Ruminococus albus and Ruminococcus flavefaciens. FEMS Microbiol Lett 204:361-366. doi:10.1111/j.1574-6968.2001.tb10911.x

Kung L, Stanley RW (1982) Effect of stage of maturity on the nutritive-value of whole-plant sugarcane preserved as silage. J Anim Sci 54:689-696. doi:10.2527/jas1982.544689x

Long M, Feng WJ, Li P, Zhang Y, He RX, Yu LH, He JB, Jing WY, Li YM, Wang Z, Liu GW (2014) Effects of the acid-tolerant engineered bacterial strain Megasphaera elsdenii $\mathrm{H} 6 \mathrm{~F} 32$ on ruminal $\mathrm{pH}$ and the lactic acid concentration of simulated rumen acidosis in vitro. Res Vet Sci 96:28-29. doi:10.1016/j. rvsc.2013.11.013

Mesquita BS (2013) Effects of sugarcane fiber digestibility and concentrate level on performance of finishing Nellore bulls. Dissertation, Universidade de São Paulo

Mosoni P, Fonty G, Gouet P (1997) Competition between ruminal cellulolytic bacteria for adhesion to cellulose. Curr Microbiol 35:44-47. doi:10.1007/ s002849900209

Mosoni P, Chaucheyras-Durand F, Bera-Maillet C, Forano E (2007) Quantification by real-time $P C R$ of cellulolytic bacteria in the rumen of sheep after supplementation of a forage diet with readily fermentable carbohydrates: effect of a yeast additive. J Appl Microbiol 103:2676-2685. doi:10.1111/j.1365-2672.2007.03517.x

Muyzer G, Dewaal EC, Uitterlinden AG (1993) Profiling of complex microbialpopulations by denaturing gradient gel-electrophoresis analysis of polymerase chain reaction-amplified genes-coding for $16 \mathrm{~s}$ ribosomalRNA. Appl Environ Microbiol 59:695-700 
Nagaraja TG, Titgemeyer EC (2007) Ruminal acidosis in beef cattle: the current microbiological and nutritional outlook. J Dairy Sci 90(Suppl 1):E17-E38. doi:10.3168/jds.2006-478

Ouwerkerk D, Klieve AV, Forster RJ (2002) Enumeration of Megasphaera elsdenii in rumen contents by real-time Taq nuclease assay. J Appl Microbiol 92:753-758. doi:10.1046/j.1365-2672.2002.01580.x

Owens FN, Goetsch AL (1993) Ruminal Fermentation. In: Church DC (ed) The ruminant animal: digestive physiology and nutrition, 5th edn. Englewood Cliffs, New Jersey, pp 145-171

Owens FN, Secrist DS, Hill WJ, Gill DR (1998) Acidosis in cattle: a review. J Anim Sci 76:275-286. doi:10.2527/1998.761275x

Pereira ES, Queiroz AC, Paulino MF, Cecon PR, Filho SCV, Miranda LF, Arruda AMV, Fernandes AM, Cabral LS (2001) Sources of non-protein nitrogen and the addition of Sacharomyces cerevisiae to sugar cane based diets for young bulls: intake, digestibility, nitrogen balances and ruminal parameters. Braz J Anim Sci 30:563-572. doi:10.1590/S1516-35982001000200036

Petri RM, Forster RJ, Yang W, McKinnon JJ, McAllister TA (2012) Characterization of rumen bacterial diversity and fermentation parameters in concentrate fed cattle with and without forage. J Appl Microbiol 112:1152-1162. doi:10.1111/j.1365-2672.2012.05295.x

Ribeiro Junior CS, Messana JD, Granja-Salcedo YT, Canesin RC, Fiorentini G, San Vito E, Furlan LR, Reis RA, Berchielli TT (2016) Parameters of fermentation and rumen microbiota of Nellore steers fed with different proportions of concentrate in fresh sugarcane containing diets. Arch Anim Nutr 70:402-415. doi:10.1080/1745039X.2016.1206737

Russell JB, Hino T (1985) Regulation of lactate production in Streptococcus bovis - a spiraling effect that contributes to rumen acidosis. J Dairy Sc 68:1712-1721. doi:10.3168/jds.S0022-0302(85)81017-1

Russell JB, Rychlik JL (2001) Factors that alter rumen microbial ecology. Science 292:1119-1122. doi:10.1126/science.1058830

Schwartzkopf-Genswein KS, Beauchemin KA, Gibb DJ, Crews DH Jr, Hickman DD, Streeter M, McAllister TA (2003) Effect of bunk management on feeding behavior, ruminal acidosis and performance of feedlot cattle: a review. J Anim Sci 81:E149-E158. doi:10.2527/2003.8114_suppl_2E149x

Shi Y, Odt CL, Weimer PJ (1997) Competition for cellulose among three predominant ruminal cellulolytic bacteria under substrate-excess and substrate-limited conditions. Appl Environ Microb 63:734-742

Singh KM, Pandya PR, Tripathi AK, Patel GR, Parnerkar S, Kothari RK, Joshi CG (2014) Study of rumen metagenome community using qPCR under different diets. Meta Gene 2:191-199. doi:10.1016/j.mgene.2014.01.001
Sousa DO, Mesquita BS, Diniz-Magalhaes J, Bueno ICS, Mesquita LG, Silva LFP (2014) Effect of fiber digestibility and conservation method on feed intake and the ruminal ecosystem of growing steers. J Anim Sci 92:5622-5634. doi:10.2527/jas2014-8016

Stevenson DM, Weimer PJ (2007) Dominance of Prevotella and low abundance of classical ruminal bacterial species in the bovine rumen revealed by relative quantification real-time PCR. Appl Microbiol Biotechnol 75:165-174. doi:10.1007/s00253-006-0802-y

Sun XQ, Wang YP, Chen B, Zhao X (2015) Partially replacing cornstarch in a high-concentrate diet with sucrose inhibited the ruminal trans-10 biohydrogenation pathway in vitro by changing populations of specific bacteria. J Anim Sci Biotechnol. doi:10.1186/s40104-015-0051-y

Tafaj M, Kolaneci V, Junck B, Maulbetsch A, Steingass H, Drochner W (2005) Influence of fiber content and concentrate level on chewing activity, ruminal digestion, digesta passage rate and nutrient digestibility in dairy cows in late lactation. Asian Australas J Anim Sci 18:1116-1124. doi:10.5713/ajas.2005.1116

Tajima K, Aminov RI, Nagamine T, Matsui H, Nakamura M, Benno Y (2001) Diet-dependent shifts in the bacterial population of the rumen revealed with real-time PCR. Appl Environ Microbiol 67:2766-2774. doi:10.1128/ AEM.67.6.2766-2774.2001

Vallimont JE, Bargo F, Cassidy TW, Luchini ND, Broderick GA, Varga GA (2004) Effects of replacing dietary starch with sucrose on ruminal fermentation and nitrogen metabolism in continuous culture. J Dairy Sci 87:42214229. doi:10.3168/jds.S0022-0302(04)73567-5

Varel VH, Dehority BA (1989) Ruminal cellulolytic bacteria and protozoa from bison, cattle-bison hybrids, and cattle fed three alfalfa-corn diets. Appl Environ Microbiol 55:148-153.

Wang RF, Cao WW, Cerniglia CE (1997) PCR detection of Ruminococcus spp. in human and animal faecal samples. Mol Cell Probe 11:259-265. doi:10.1006/mcpr.1997.0111

Weimer PJ (1996) Why don't ruminal bacteria digest cellulose faster? J Dairy Sci 79:1496-1502. doi:10.3168/jds.S0022-0302(96)76509-8

Yuan JS, Reed A, Chen F, Stewart CN (2006) Statistical analysis of real-time PCR data. BMC Bioinform. doi:10.1186/1471-2105-7-85

\section{Submit your manuscript to a SpringerOpen ${ }^{\circ}$ journal and benefit from:}

- Convenient online submission

- Rigorous peer review

- Immediate publication on acceptance

- Open access: articles freely available online

- High visibility within the field

- Retaining the copyright to your article

Submit your next manuscript at $>$ springeropen.com 